Short Communication

\title{
Evaluation of Antioxidant Potential of Vegetables Waste
}

\author{
Adil Munir', Bushra Sultana', Asad Bashir ${ }^{1}$, Abdul Ghaffar², Bushra Munir², \\ Ghulam Abbas Shar ${ }^{3}$, Arif Nazir ${ }^{4}$, Munawar Iqbal ${ }^{4 *}$ \\ ${ }^{1}$ Department of Chemistry, University of Agriculture Faisalabad, Pakistan \\ ${ }^{2}$ Department of Biochemistry, Government College University, Faisalabad, Pakistan \\ ${ }^{3}$ Department of Chemistry, Shah Abdul Latif University Khairpur-66020, Sindh, Pakistan \\ ${ }^{4}$ Department of Chemistry, University of Lahore, Lahore, Pakistan
}

Received: 13 February 2017

Accepted: 28 march 2017

\begin{abstract}
Vegetables are considered a rich source of such antioxidants as phenolics, carotenoids, flavonoids, and vitamins, which are frequently added to stop the process of oxidation in processed food and biological systems. This work aimed to investigate the antioxidant potential of vegetable waste (garlic, onion, and cauliflower). The extracts of vegetable waste were prepared by two solvents $-80 \%$ methanol and $80 \%$ ethanol - and were appraised for their antioxidant potential. Total phenolic contents (TPC) of these vegetable waste extracts were in the range of 2.23-16.12 mg Gallic acid equivalents/gram (GAE/g) of dry weight (DW), while total flavonoids were in the order of $0.24-2.13 \mathrm{mg}$ catechin equivalent/gram $(\mathrm{CE} / \mathrm{g})$ of DW. Maximum inhibition capacity and maximum scavenging activity was displayed by ethanolic extract of onion waste. The onion waste extract compared to others also showed high reducing power (1.27) as it had higher intensity of color. This analysis declares onion waste with maximum value of TPC, total flavonoids content (TFC), 2, 2-diphenyl-1-picryl-hydrazyl-hydrate (DPPH), and the percentage of age inhibition.
\end{abstract}

Keywords: vegetable wastes, antioxidant activity, flavonoids, polyphenols, carotenoids

\section{Introduction}

Plants have long been considered to be a dietary source of natural antioxidants. Plants have an efficient defensive system to circumvent the toxic effect of free radicals. Mitochondria and chloroplasts are the powerhouses and sites of reactive oxygen species generation. Plant-driven antioxidants or phytochemicals are the ancillary plant metabolites. Major antioxidants produced by the plants

*e-mail: chemuaf@gmail.com include terpenoids, cinnamic acids, benzoic acids, folic acid, ascorbic acid, alpha tocopherols, and tocotrienols [1-7]. It is believed that the majority of plant species have medicinal significance and excellent antioxidant potential. On a similar note, various fruits and vegetables also contain a lot of widely useful antioxidants such as beta-carotene, anthocyanins, and tocopherols, etc. Easily cultivable vegetables can be a chief source of natural antioxidants [8-12].

Antioxidants prevent the harmful effects of free radicals due to their beneficial trend in the reduction and inhibition of oxidative reactions. Antioxidants 
reduce oxidative stress at the cellular level and therefore are useful for treating several diseases in humans. Nourishments rich in fruits and vegetables are found to play a pivotal role in dipping the risk of certain types of chronic diseases [13].

Vegetable byproducts are considered to be a source of certain phytochemicals having antioxidant activity. For this purpose several vegetables have been studied, on an industrial scale, as sources of potentially safe natural antioxidants, e.g., polyphenols. A large range of plant polyphenolics have been proposed for protection against lipid oxidation. This increased interest has led to the exploration of antioxidants in many plant species. Special attention has been paid to vegetable wastes to be a rich source of phenolic compounds [14].

Onion and garlic belonging to the family Allium are two vegetables extensively used by humans on a daily basis owing to their essence and health beneficiary properties. Some researchers have reported that these vegetables can be potent cardiovascular and anticancer agents. These are a vital source of polyphenols. One of the most-consumed vegetables, cauliflower (Brassica oleracea L.), has recently become popular with its high nourishing value and post-harvest loss of cells division power, and is associated with lipid peroxidation - the cause of preferential degradation of polyunsaturated fatty acids [15].

Various vegetable byproducts have been investigated for their nutritional and medicinal attributes. This is the first attempt to evaluate the antioxidant potential and nutritional quality of vegetable wastes with respect to onion, garlic, and cauliflower.

\section{Materials and Methods}

Vegetable waste samples were obtained from canteens at the University of Agriculture, Faisalabad (UAF). The peels, leaves, and stems were separated. Samples were dried in the open air followed by oven drying, and then were ground and subjected to extraction. Extraction of the dried vegetable byproducts was carried out by aqueous methanol (80:20, methanol:water, v/v) and ethanol (80:20, ethanol:water, v/v) and were shaken in a Gallenkamp (UK) shaker. All acquired extracts were filtered and the process was repeated three times. The combined extracts were concentrated using a rotary evaporator.

The amount of total phenolic contents (TPC) was assessed using Folin-Ciocalteu reagent procedure as described by Chaovanalikit and Wrolstad [16]. Total flavonoid contents (TFC) were determined following the procedure described by Dewanto et al. [17]. The antioxidant activity of extracts was also determined in terms of measurement of percent inhibition of peroxidation in the linoleic acid system following a reported method [18]. The reducing power of the extracts was determined according to the procedure described by Yen et al. [19], with slight modification.

Free radical scavenging activities of the extract were measured using the procedure described by Iqbal and Bhanger [18]. Three samples of each sample were assayed. Each extract was analyzed individually in triplicate. Data were analyzed using analysis of variance (ANOVA) at 5\% significance level.

\section{Results and Discussion}

Table 1 shows the percentage extract yield from some vegetable wastes (onion, garlic, and cauliflower). The yield of vegetable waste extracts ranged $6.47-19.85 \%$ of dry weight. The greatest input (19.85) was acquired from cauliflower, whereas the least $(6.47 \%)$ was from garlic waste.

Total phenolic contents (TPC) in extracts of vegetable byproducts were analyzed using the Folin-Ciocalteau method. This technique was employed owing to its sensitivity, least interference, and fortification to compute the TPC [20]. We observed that TPC of cauliflower waste extracts were found in the range 2.23-3.45 mg gallic acid equivalents/gram (GAE/g), and garlic and onion waste extracts ranged 4.80-6.47 mg GAE/g and 12.87-16.12 mg GAE/g of dry weight (DW) respectively. However, TPC of onion waste (ethanolic extract) was found to be highest (16.12mg GAE/g DW), while that of cauliflower waste (methanolic extract) was the lowest (2.23mg GAE/g DW). The attributes of phenolic contents scrutinized in this research were comparable to those reported earlier for garlic (9 mg GAE/g) and onion (15.87 mg GAE/g). Prakash et al. [21] described similar results for phenolic contents in onion (4.6-74.4mg GAE/g), and Miean and Mohamed [22] reported comparable results for cauliflower. The polyphenolic profile found in this work is in agreement with previous studies [23-28].

The amount of TF observed in cauliflower waste extracts ranged $0.24-0.35 \mathrm{mg}$ catechin equivalent/gram $(\mathrm{CE} / \mathrm{g})$, and garlic and onion waste extracts were found in the range $0.62-0.83 \mathrm{mg} \mathrm{CE} / \mathrm{g}$ and $1.72-2.13 \mathrm{mg} \mathrm{CE} / \mathrm{g}$ of DW, respectively. The greatest input of flavonoids (2.13 mg CE/g DW) was attained from onion (ethanolic

Table 1. Percentage yield, TPC, and TFC of onion, garlic, and cauliflower waste.

\begin{tabular}{|c|c|c|c|c|}
\hline Solvent & Varieties & Yield & TPC & TFC \\
\hline \multirow{3}{*}{$\begin{array}{c}80 \% \\
\text { Ethanol }\end{array}$} & Onion & $16 \pm 0.25$ & $16.12 \pm 0.67$ & $2.13 \pm 0.4$ \\
\cline { 2 - 5 } & Garlic & $6.47 \pm 0.12$ & $4.80 \pm 0.50$ & $0.62 \pm 0.08$ \\
\cline { 2 - 5 } & Cauliflower & $19.85 \pm 0.87$ & $3.45 \pm 0.27$ & $0.35 \pm 0.06$ \\
\hline \multirow{3}{*}{$\begin{array}{c}80 \% \\
\text { Methanol }\end{array}$} & Onion & $15.85 \pm 0.62$ & $12.87 \pm 0.90$ & $1.72 \pm 0.07$ \\
\cline { 2 - 5 } & Garlic & $8.51 \pm 0.42$ & $6.91 \pm 0.41$ & $0.83 \pm 0.07$ \\
\cline { 2 - 5 } & Cauliflower & $16.70 \pm 0.35$ & $2.23 \pm 0.62$ & $0.24 \pm 0.02$ \\
\hline
\end{tabular}

Values (mean $\pm \mathrm{SD}$ ) are average of three samples of each vegetable waste analyzed individually in triplicate $(n=3 \times 3)$, $(P<0.05)$; TPC: total phenolic contents; TFC: total flavonoid contents 
extract), while the minimum value $(0.24 \mathrm{mg} \mathrm{CE} / \mathrm{g}$ DW) was observed from cauliflower (methanolic extract). With regard to solvents efficiency, $80 \%$ ethanol was found to be more efficient for the recovery of antioxidant compounds from vegetable wastes as compared to $80 \%$ methanol. The values investigated in this research were comparable to those stated by [22] for flavonoid contents in garlic, onion, and cauliflower. Antioxidant mechanisms and activity are highly reliant on type and concentration of solvent [29], but they also vary within the samples. Kabir et al. [30] reported that fruit and vegetable byproducts have good antioxidant properties owing to the presence of a good amount of phenolic components. Waste products from the vegetables and fruits, thrown into the environment, are the natural and economic sources of antioxidant and antimicrobial activities. These products can be effectively employed for the prevention of many diseases caused by the pathogenic microbes [31].

\section{Linoleic Acid System (Antioxidant Activity)}

The values of inhibition of vegetable byproducts in alcoholic (methanol and ethanol) extracts ranged 59.34$73.13 \%$ and $53.64-75.54 \%$, respectively (Fig. 1a). These
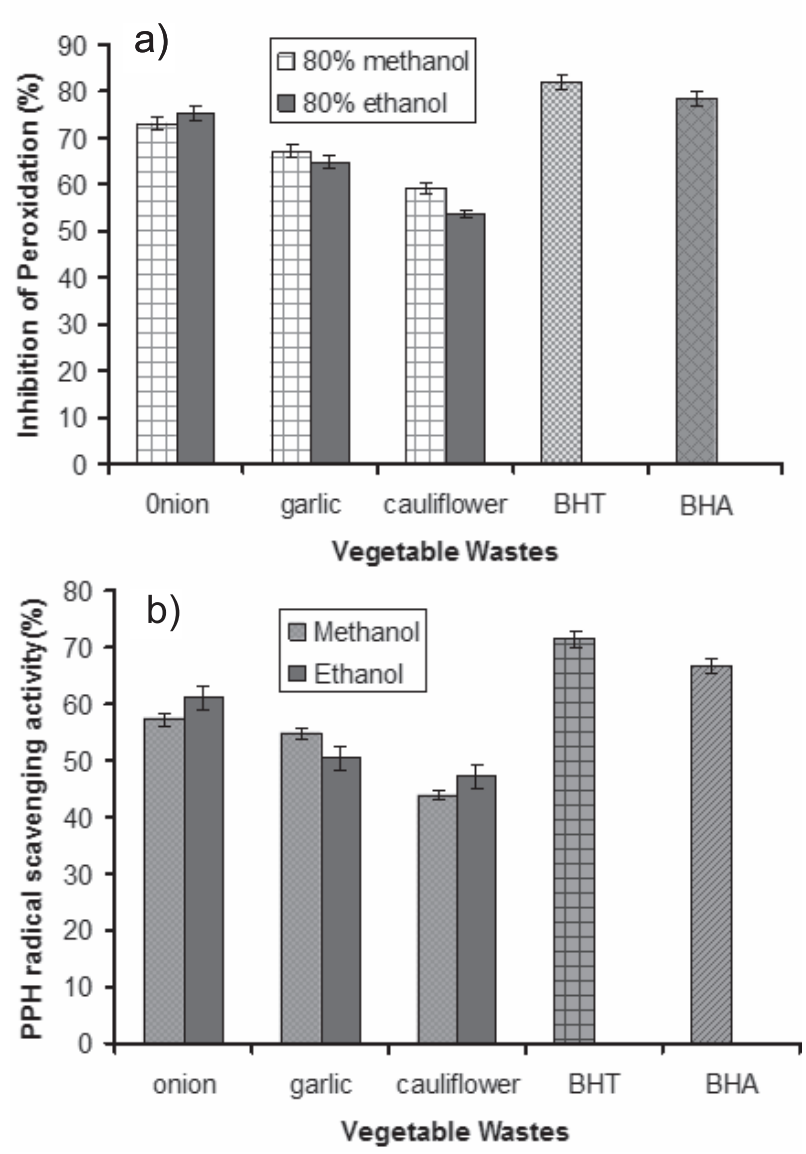

Fig. 1. a) Percentage of inhibition of linoleic acid of onion, garlic, and cauliflower waste and b) DPPH radical scavenging activity of onion, garlic, and cauliflower waste. values of scavenging activity were equated with butylated hydroxytoluene (BHT) and (butylated hydroxyanisole (BHA) (81.89 and 78.56\%). Cauliflower wastes showed minimum inhibition activity while onion wastes showed the maximum. Ethanolic extract of onion waste was found to show maximum reticence of peroxidation and therefore replicating the highest antioxidant, while bottommost inhibition was perceived by ethanol extract of cauliflower wastes. The data obtained in this study was comparable to the one stated for the chestnut fruit [32]. Arithmetical analysis showed the substantial $(\mathrm{p}<0.05)$ differences of $\%$ inhibition in the extracts of vegetable wastes (onion, garlic, and cauliflower).

\section{Free Radical Scavenging Activity Using DPPH Radical}

Free radicals being the initiators of many degenerative processes may damage lipids, proteins, and deoxyribonucleic acid (DNA), and favors the development of many chronic diseases. The diseases caused by oxidative stress can be prevented by the consumption of food rich in natural antioxidants (Joshi et al., 2012). DPPH scavenging activity is the most widely used method for screening antioxidant capacity of plant extract [33]. Results obtained from the current work show that the scavenging activity of vegetable wastes in $80 \%$ methanol and $80 \%$ ethanol extracts ranged $43.98-57.37 \%$ and $47.28-61.13 \%$, respectively (Fig. 1b). The highest activity was accomplished from ethanolic extract of onion wastes and the lowest from methanolic extract of cauliflower byproduct, which is due to the fact that onion waste has a large number of phenolic compounds that have the ability to donate hydrogen ions that increased the scavenging activity of free radicals. These data were linked with the control (BHT and BHA) and were 71.56 and $66.78 \%$. The results were comparable to those described for apples [34] and vegetables [35]. Numerical analysis has shown the significant $(\mathrm{p}<0.05)$ variances of percentage of DPPH in the extracts of vegetable byproducts. The phenolic compounds found in the vegetable byproducts have antioxidant properties such as oxygen scavengers and free radical inhibitors.

\section{Reducing Power}

Table 2 shows the reducing power of vegetable byproduct extracts. The reducing power for ethanolic extracts ranged $0.941-1.27$, and in $80 \%$ methanol extracts ranged $0.893-1.13$ at the concentration of $10 \mathrm{mg} / \mathrm{ml}$. From the analysis we observed that the onion waste extract had high reducing power as it had higher intensity of color, while the cauliflower waste extract had lower reducing power as it intensity of color was low. The data of reducing power found in the current scrutiny were less than those stated for chestnut fruit [32]. Based on the results, the extracted polyphenolic compounds can be employed to develop an eco-friendly management system for the agro-food sector. The present study revealed that 
Table 2. Reducing power of extracts of vegetable wastes.

\begin{tabular}{|c|c|c|c|c|c|c|c|c|}
\hline \multirow{2}{*}{ Variety } & \multicolumn{4}{|c|}{$80 \%$ Ethanol } & \multicolumn{4}{c|}{$80 \%$ Methanol } \\
\cline { 2 - 9 } & \multicolumn{3}{|c|}{ Extracts Conc. Mg/mL } & \multicolumn{4}{c|}{ Extracts Conc. Mg/mL } \\
\cline { 2 - 9 } & 2 & 5 & 7 & 10 & 2 & 5 & 7 & 10 \\
\hline Onion & $0.322 \pm 0.03$ & $0.632 \pm 0.05$ & $0.882 \pm 0.11$ & $1.27 \pm 0.07$ & $1.27 \pm 0.07$ & $0.299 \pm 0.04$ & $0.610 \pm 0.07$ & $0.855 \pm 0.15$ \\
\hline Garlic & $0.271 \pm 0.02$ & $0.577 \pm .09$ & $0.811 \pm .04$ & $0.987 \pm 0.12$ & $0.987 \pm 0.12$ & $0.282 \pm 0.03$ & $0.597 \pm 0.05$ & $0.843 \pm 0.20$ \\
\hline Cauliflower & $0.235 \pm 0.03$ & $0.541 \pm 0.05$ & $0.790 \pm 0.04$ & $0.941 \pm 0.12$ & $0.941 \pm 0.12$ & $0.210 \pm 0.05$ & $0.513 \pm 0.03$ & $0.763 \pm 0.14$ \\
\hline
\end{tabular}

Values (mean $\pm \mathrm{SD}$ ) are average of three samples of each vegetable waste, analyzed

individually in triplicate $(\mathrm{n}=3 \times 3),(\mathrm{P}<0.05)$; SD: Standard Deviation

our investigated vegetable waste had considerable antioxidant activity since vegetables are potent sources of bioactive compounds [36-49]. So far, the recycling/ utilization of such waste is a good option that will be helpful for avoiding environmental-related issues [50-73]

\section{Conclusions}

The antioxidant compounds were extracted (using ethanol) from vegetable (onion, garlic, and cauliflower) wastes, and the extracts showed their promising antioxidant activity. We concluded that the vegetable wastes represent a good source of natural antioxidants and they could be considered as useful sources of bioactive compounds. The extraction bioactive compounds present in vegetable by-products should be recovered.

\section{References}

1. ADAMCOVÁ D., VAVERKOVÁ M.D., STEJSKAL B., BROUSKOVA E. Household solid waste composition focusing on hazardous waste. Pol. J. Environ. Stud. 25 (2), 487, 2016.

2. DAUD M.K., HASSAN S., AZIZULLAH A., JAMIL M., REHAN N., IRUM R., QAISER M.K., ZHU S.J. Physiological, biochemical, and genotoxic effects of wastewater on maize seedlings. Pol. J. Environ. Stud. 2, (2), 563, 2016.

3. GHASEMI M.K., YUSUFF R.B.M. Advantages and disadvantages of healthcare waste treatment and disposal alternatives: Malaysian scenario. Pol. J. Environ. Stud. 25 (1), 17, 2016.

4. HAI T., WEN-CHENG P., CHANG-FENG C., JIAN-PING X., WEN-JUN H. Remediation of acid mine drainage based on a novel coupled membrane-free microbial fuel cell with permeable reactive barrier system. Pol. J. Environ. Stud. 2, (1), 107, 2016.

5. TANEE T., SUDMOON R., THAMSENANUPAP P., CHAVEERACH A. Effect of Cadmium on DNA Changes in Ipomoea aquatica Forssk. Pol. J. Environ. Stud. 25 (1), 311, 2016.

6. TIAN F., LIU Y., LIU C., GU H., LIU H. Pollution status and multimedia fate simulation of phthalate acid esters (PAEs) in an arid city. Pol. J. Environ. Stud. 25 (1), 325, 2016.
7. UL HAQ Z., JAMIL Y., IRUM S., RANDHAWA M.A., IQBAL M., AMIN N. Enhancement in the germination, seedling growth and yield of radish (Raphanus sativus) using seed pre-sowing magnetic field treatment. Pol. J. Environ. Stud. 21, 369, 2012.

8. BHARTI R., AHUJA G., SUJAN G., DAKAPPA S.S. A review on medicinal plants having Antioxidant potential. J Pharm. Res. 5, 4278, 2012.

9. ADARAMOLA B., ONIGBINDE A. Influence of extraction technique on the mineral content and antioxidant capacity of edible oil extracted from ginger rhizome. Chem. Int. $\mathbf{3}$, $1,2017$.

10. ADARAMOLA B., ONIGBINDE A., SHOKUNBI O. Physiochemical properties and antioxidant potential of Persea Americana seed oil. Chem. Int. 2, 168, 2016.

11. ASIF M. Pharmacologically potentials of different substituted coumarin derivatives. Chem. Int. 1, 1, 2015.

12. ASIF M. Chemistry and antioxidant activity of plants containing some phenolic compounds. Chem. Int. 1, 35, 2015.

13. AJILA C., NAIDU K., BHAT S., RAO U.P. Bioactive compounds and antioxidant potential of mango peel extract. Food chem. 105, 982, 2007.

14. SPEISKY H., LÓPEZ-ALARCÓN C., GÓMEZ M., FUENTES J., SANDOVAL-ACUÑA C. First web-based database on total phenolics and oxygen radical absorbance capacity (ORAC) of fruits produced and consumed within the south Andes region of South America. J. Agric. Food Chem. 60, 8851, 2012.

15. SCALZO R.L., BIANCHI G., GENNA A., SUMMA C. Antioxidant properties and lipidic profile as quality indexes of cauliflower (Brassica oleracea L. var. botrytis) in relation to harvest time. Food chem. 100, 1019, 2007.

16. CHAOVANALIKIT A., WROLSTAD R. Total anthocyanins and total phenolics of fresh and processed cherries and their antioxidant properties. J. Food Sci. 69 , FCT67-FCT72, 2004.

17. DEWANTO V., WU X., ADOM K.K., LIU R.H. Thermal processing enhances the nutritional value of tomatoes by increasing total antioxidant activity. J. Agric. Food Chem. 50, 3010, 2002.

18. IQBAL S., BHANGER M., ANWAR F. Antioxidant properties and components of some commercially available varieties of rice bran in Pakistan. Food Chem. 93, 265,2005

19. YEN G-C., DUH P-D., CHUANG D-Y. Antioxidant activity of anthraquinones and anthrone. Food Chem. 70, 437, 2000.

20. SULTANA B., ANWAR F., PRZYBYLSKI R. Antioxidant activity of phenolic components present in barks of 
Azadirachta indica, Terminalia arjuna, Acacia nilotica, and Eugenia jambolana Lam. trees. Food Chem. 104, 1106, 2007.

21. PRAKASH D., SINGH B.N., UPADHYAY G. Antioxidant and free radical scavenging activities of phenols from onion (Allium cepa). Food Chem. 102, 1389, 2007.

22. MIEAN K.H., MOHAMED S. Flavonoid (myricetin, quercetin, kaempferol, luteolin, and apigenin) content of edible tropical plants. J. Agric. Food Chem. 49, 3106, 2001.

23. AIRES A., CARVALHO R., SAAVEDRA M.J. Reuse potential of vegetable wastes (broccoli, green bean and tomato) for the recovery of antioxidant phenolic acids and flavonoids. International J. Food Sci. \& Technol. 52, 98, 2017.

24. DEVAPPA R.K., RAKSHIT S.K., DEKKER R.F. Forest biorefinery: potential of poplar phytochemicals as value-added co-products. Biotechnol. Adv. 33, 681, 2015.

25. JOSEPH O., PHELOMENE M., HELENE N., VALENS H., PATRICK O.M., THAVARAJAH P. Phenolic compound profiles of two common beans consumed by Rwandans. Am. J. Plant Sci. 5 (20), 2943, 2014.

26. KATSAMPA P., VALSAMEDOU E., GRIGORAKIS S., MAKRIS D.P. A green ultrasound-assisted extraction process for the recovery of antioxidant polyphenols and pigments from onion solid wastes using Box-Behnken experimental design and kinetics. Ind. Crops Prod. 77, 535, 2015.

27. HARWANSH R.K., MUKHERJEE P.K., BAHADUR S., BISWAS R. Enhanced permeability of ferulic acid loaded nanoemulsion based gel through skin against UVA mediated oxidative stress. Life Sci. 141, 202, 2015.

28. SOUSA C., TAVEIRA M., VALENTÃO P., FERNANDES F., PEREIRA J.A., ESTEVINHO L., BENTO A., FERRERES F., SEABRA R.M., ANDRADE P.B. Inflorescences of Brassicacea species as source of bioactive compounds: A comparative study. Food Chem. 110, 953, 2008.

29. TURKMEN N., SARI F., VELIOGLU Y.S. Effects of extraction solvents on concentration and antioxidant activity of black and black mate tea polyphenols determined by ferrous tartrate and Folin-Ciocalteu methods. Food Chem. 99, 835, 2006

30. KABIR F., TOW W.W., HAMAUZU Y., KATAYAMA S., TANAKA S., NAKAMURA S. Antioxidant and cytoprotective activities of extracts prepared from fruit and vegetable wastes and by-products. Food Chem. 167, 358, 2015.

31. JOSHI V., KUMAR A., KUMAR V. Antimicrobial, antioxidant and phyto-chemicals from fruit and vegetable wastes: A review. Int. J. Food Ferment. Technol. 2 (2), 123, 2012.

32. BARREIRA J.C., FERREIRA I.C., OLIVEIRA M.B.P., PEREIRA J.A. Antioxidant activities of the extracts from chestnut flower, leaf, skins and fruit. Food Chem. 107, 1106, 2008.

33. MALA K.S., KURIAN A.E. Nutritional Composition and Antioxidant Activity of Pumpkin Wastes. Int. J. Pharma. Chem. Bio. Sci. 6 (3), 336, 2016.

34. PESCHEL W., SÁNCHEZ-RABANEDA F., DIEKMANN W., PLESCHER A., GARTZÍA I., JIMÉNEZ D., LAMUELA-RAVENTOS R., BUXADERAS S., CODINA C. An industrial approach in the search of natural antioxidants from vegetable and fruit wastes. Food Chem. 97, 137, 2006.
35. HALA M.A. Comparative antioxidant activity study of some edible plants used spices in Egypt. J. Am. Sci. 7, 1118, 2011.

36. ASIF M. Antiviral and antiparasitic activities of various substituted triazole derivatives: A mini, Chem. Int. 1, 71, 2015.

37. ASIF M. Chemical characteristics and nutritional potentials of unsaturated fatty acids, Chem. Int. 1, 118, 2015.

38. ASIF M. Anti-tubercular activity of some six membered heterocycle compounds, Chem. Int. 1, 134, 2015.

39. ASIF M. Anti-neuropathic and anticonvulsant activities of various substituted triazoles analogues, Chem. Int. 1, 174, 2015.

40. ASIF M. A review on recent advances and potential pharmacological activities of versatile chalchone molecule, Chem. Int. 2, 1, 2016.

41. ABATE L., ABEBE A., MEKONNEN A.. Studies on antioxidant and antibacterial activities of crude extracts of Plantago lanceolata leaves. Chem. Int. 3, 277, 2017.

42. AMOS-TAUTUA B., AJILEYE O., NDONIS., BAMIDELE F., ONIGBINDE A., Evaluation of phenolic contents, free radical scavenging activity and functional group analysis of the leaf extract of a medicinal plant in Niger Delta Region, Chem. Int. 3, 250, 2017.

43. BENOUIS K., Phytochemicals and bioactive compounds of pulses and their impact on health. Chem. Int. 3, 224, 2017.

44. CAHYANA A.H., KAM N., ELLYN, Study on the stability of antioxidant and anti- $\alpha$-glucosidase activities using soaking treatment of Okra (Abelmoschus esculentus L.) mucilage extracts. Chem. Int. 3, 203, 2017.

45. GANGADHARA R., PRASAD N., Studies on optimization of transesterification of certain oils to produce biodiesel, Chem. Int. 2, 59, 2016.

46. HAILU Y.M., ATLABACHEW M., CHANDRAVANSHI B.S., REDI-ABSHIRO M., Composition of essential oil and antioxidant activity of Khat (Catha edulis Forsk), Ethiopia, Chem. Int. 3, 25, 2017.

47. HAMID A.A., OGUNTOYE S.O., ALLI S.O., AKOMOLAFE G.A., ADERINTO A., OTITIGBE A., OGUNDARE A.M., ESINNIOBIWA Q.M., AMINU R.O., Chemical composition, antimicrobial and free radical scavenging activities of Grewia pubescens, Chem. Int. 2, 254, 2016.

48. HIWOT T., Determination of oil and biodiesel content, physicochemical properties of the oil extracted from avocado seed (Persea Americana) grown in Wonago and Dilla (gedeo zone), southern Ethiopia, Chem. Int. 3, 311, 2017.

49. ISAH S., OSHODI A.A., ATASIE V.N., Physicochemical properties of cross linked acha (digitaria exilis) starch with citric acid. Chem. Int. 3, 150, 2017.

50. A. BABARINDE, K. OGUNDIPE, K.T. SANGOSANYA, B.D. AKINTOLA, A.-O. ELIZABETH HASSAN, Comparative study on the biosorption of $\mathrm{Pb}(\mathrm{II}), \mathrm{Cd}(\mathrm{II})$ and $\mathrm{Zn}(\mathrm{II})$ using Lemon grass (Cymbopogon citratus): kinetics, isotherms and thermodynamics, Chem. Int. 2, 89, 2016.

51. BABARINDE A., ONYIAOCHA G.O., Equilibrium sorption of divalent metal ions onto groundnut (Arachis hypogaea) shell: kinetics, isotherm and thermodynamics, Chem. Int. 2, 37, 2016.

52. BENABDALLAH N.K., HARRACHE D., MIR A., DE LA GUARDIA M., BENHACHEM F.-Z. Bioaccumulation of trace metals by red alga Corallina elongata in the coast of Beni Saf, west coast, Algeria. Chem. Int. 3, 220, 2017. 
53. IQBAL M., KHERA R.A. Adsorption of copper and lead in single and binary metal system onto Fumaria indica biomass, Chem. Int. 1, 157b, 2015.

54. JAFARINEJAD S. Control and treatment of sulfur compounds specially sulfur oxides (SOx) emissions from the petroleum industry: a review, Chem. Int. 2, 242, 2016.

55. JAFARINEJAD S. Recent developments in the application of sequencing batch reactor (SBR) technology for the petroleum industry wastewater treatment, Chem. Int. 3, 241, 2017.

56. JAMAL M.A., MUNEER M., IQBAL M. Photo-degradation of monoazo dye blue 13 using advanced oxidation process, Chem. Int. 1, 12, 2015.

57. LEGROURI K., KHOUYA E., HANNACHE H., EL HARTTI M., EZZINE M., NASLAIN R. Activated carbon from molasses efficiency for $\mathrm{Cr}(\mathrm{VI}), \mathrm{Pb}(\mathrm{II})$ and $\mathrm{Cu}(\mathrm{II})$ adsorption: A mechanistic study. Chem. Int. 3, 301, 2017.

58. MAJOLAGBE A.O., ADEYI A.A., OSIBANJO O. Vulnerability assessment of groundwater pollution in the vicinity of an active dumpsite (Olusosun), Lagos, Nigeria, Chem. Int. 2, 232, 2016.

59. MAJOLAGBE A.O.,ADEYIA.A., OSIBANJO O., ADAMS A.O., OJURI O.O. Pollution vulnerability and health risk assessment of groundwater around an engineering Landfill in Lagos, Nigeria, Chem. Int. 3, 58, 2017.

60. OGUNDIPE K.D., BABARINDE A. Comparative study on batch equilibrium biosorption of $\mathrm{Cd}(\mathrm{II}), \mathrm{Pb}(\mathrm{II})$ and $\mathrm{Zn}$ (II) using plantain (Musa paradisiaca) flower: kinetics, isotherm, and thermodynamics. Chem. Int. 3, 135, 2017.

61. PETER U.C., CHINEDU U. Model prediction for constant area, variable pressure drop in orifice plate characteristics in flow system, Chem. Int. 2, 80, 2016.

62. QURESHI K., AHMAD M., BHATTI I., IQBAL M., KHAN A. Cytotoxicity reduction of wastewater treated by advanced oxidation process, Chem. Int. 1, 53, 2015.
63. SAYED M. Efficient removal of phenol from aqueous solution by the pulsed high-voltage discharge process in the presence of $\mathrm{H}_{2} \mathrm{O}_{2}$, Chem. Int. 1, 81, 2015.

64. UKPAKA V Development of model for bioremediation of crude oil using moringa extract, Chem. Int. 2, 19, 2016.

65. UKPAKA V Predictive model on the effect of restrictor on transfer function parameters on pneumatic control system, Chem. Int. 2, 128, 2016.

66. UKPAKA C. Empirical model approach for the evaluation of $\mathrm{pH}$ and conductivity on pollutant diffusion in soil environment, Chem. Int. 2, 267, 2016.

67. UKPAKA C. BTX Degradation: The concept of microbial integration, Chem. Int. 3, 8, 2016.

68. UKPAKA C., IZONOWEIT. Model Prediction on the Reliability of Fixed Bed Reactor for Ammonia Production, Chem. Int. 3, 46, 2017.

69. UKPAKA C., UKPAKA C. Characteristics of groundwater in Port-Harcourt local Government area, Chem. Int. 2, 136, 2016.

70. UKPAKA C.P., IGWE F.U. Modeling of the velocity profile of a bioreactor: the concept of biochemical process. Chem. Int. 3, 258, 2017.

71. STANISZEWSKI R. Heavy Metals in Waters and Sediments of Rivers Affected by Brown Coal Mine Waters Pol. J. Environ. Stud. 23, 6, 2217, 2014.

72. KALEMBKIEWICZ J., CHMIELARZ U. Effects of Biomass Co-Combustion with Coal on Functional Speciation and Mobility of Heavy Metals in Industrial Ash. Pol. J. Environ. Stud. 22, 3, 741, 2013.

73. ERDOGAN S., BAYSAL A., AKBA O., HAMAMCI C. Interaction of Metals with Humic Acid Isolated from Oxidized Coal. Pol. J. Environ. Stud. 16, 5, 671, 2007. 